\title{
MTF-1 Inhibitor APTO-253 HCl
}

National Cancer Institute

\section{Source}

National Cancer Institute. MTF-1 Inhibitor APT O-253 HCl. NCl Thesaurus. Code C95724.

The hydrochloride salt of a small molecule inhibitor of human metal-regulatory transcription factor 1 (MTF-1) with potential antitumor activity. MTF-1 inhibitor APT O253 inhibits MTF-1 activity and thereby induces the expression of MTF-1 dependent tumor suppressor factor Kruppel like factor 4 (KLF4). This subsequently leads to the downregulation of cyclin D1, blocking cell cycle progression and proliferation. This agent also causes decreased expression of genes involved in tumor hypoxia and ang iogenesis. 